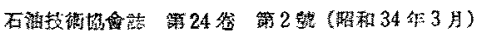

JÓURNAL OF THE JAPANESE ASSOCIATION OF PETROLEUM TECHNOLOGISTS

VOL. 24. NO. 2 (March 1959)

軟体動物化石から夕た房総・三浦雨半島の三浦愿群の

年代および対比の問題（その1）

生.越忠

(1959 年 1 月 13 日受理)

\title{
Some Problems Concerning the Geological Age and Correlation of the Miura Group on the Bôsō and Miura Peninsulas, South Kantô, Japan, \\ Viewed from the Molluscan Faunistic Sequence.
}

By

\section{Sunao OGOSE}

Abstract: Defferent opinions concerning the geological age and correlation of the Cenozoic strata developed on the Bôsố and Miura Peninsulas, South Kantô, Japan, have hitherto been expressed by many Japanese geologists and paleontologists.

The Cenozoic strata developed on the Bôsó and Miura Peninsulas are divided lithologically into two groups, the lower, the Miura, and the upper, the Narita.

In the present paper, the writer deals with some problems concerning the geological age and correlation of the Miura group.

1) From the viewpoint of the Molluscan faunistic sequence, the Takoegawa sandstone and conglomerate and Zusi mudstone on the Miura Peninsula may safely be correlated to the Mane mudstone, Motona sandstone and conglomerate, Siroiwa alternation and Kiyosumi sandstone on the Bósó Peninsula, and the Kanazawa superformaton on the Miura Peninsula may be correlated to the Seki subgroup on the Bôsó Peninsula.

2) No incontrovertible direct paleontologic evidence is yet known, however, the approximate position of the Miocene-Pliocene boundary in the Bôsô and Miura Peninsulas can be determined by the biochronologic analysis of the Molluscan fossils collected from various horizons in the Miura group.

According to the recent opinion of K. HATAl, the Miocene-Pliocene boundary in the Bôsô Peninsula corresponds with the so-called "Kurotaki unconformity" placed at the base of the Kurotaki formation and its correlatives. However, the writer is inclined to consider that this boundary in the Bôsô Peninsula is possibly placed below the Kiyosumi sandstone and its correlatives from which the so-called Dainiti-type Molluscans are collected. In the Miura Peninsula, the Takoegawa sandstone and conglomerate and Zusi mudstone may be considered as ranging from the Upper Miocene up to the Lower Pliocene. Therefore, no major stratigraphic break is found near the transition. stage from Miocene to Pliocene time throughout the Bôsó and Miura Peninsulas. 
3) The position of the Pliocene-Pleistocene boundary in the BÔso and Miura Peninsulas is currently. one of the most controversial problems in Japanese Cenozoic stratigraphy.

Although a great number of marine Molluscan fossils have been found in various horizons of the Pliocene and Pleistocene strata in the BÓsó and Miura Peninsulas, it is extremely difficult to determine where the Pliocene-Pleistocene boundary is, and opinions are still conflicting with one another on this problem.

According to the writer's opinion, however, the Ôtadai alternation of sandstone and mudstone, Umegase sandstone and alternation of sandstone and mudstone and their correlatives in the $B \delta \delta_{s} 0$ Peninsula as well as the Kosiba tuffaceous sand in the Miura Peninsula may be considered to be Lower Pleistocene. The percentages of the living species of Molluscan fossils collected from these formations show tolerably high values.

\section{I.まえがき}

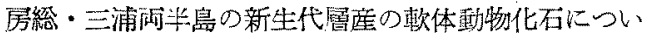
ては，古くから，多くの人たらが研究しているが棓1), これらの化石にもとづいて，呵半島の新生代尿の年代特 よび対比の問題を論じる段階になると，乙こには，要 た，多くの芫解の不一致が存在している。

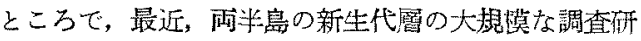
梦が，関東油田・ガス田の開登計画の一環として, 石沾 資源開登株式会社招上び工業技狱院地筫調查所などの諸 機関によって進められてきたが，この調查䀒究の一部苂

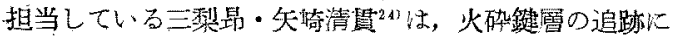
よって, 两半泉の第三紀屬の一部の対比をこ〉ろみ, そ の成果の一部を，すで本誌上に発彗した。

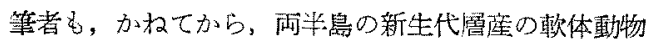
化石について，研究を進めてきたが，小論では，雨娄島

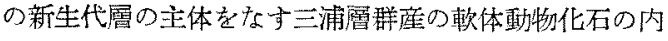

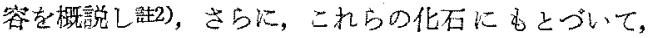

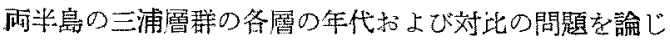
て双たいと思う。

\section{II. 三浦層群について}

房総・三浦丽半島の新生代桪の区分については，往来 から，いるいるな見解が爷表されているが，その主体を なす三浦厤䛨の区分についてる，その下限执よび上限を

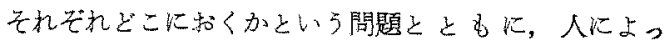
て，見解ががなことなっている註3)。

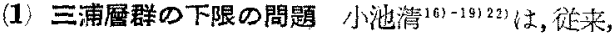

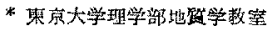

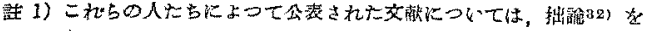
照。

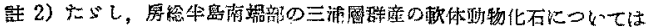

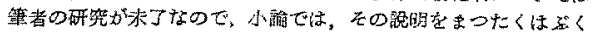
ことにする。

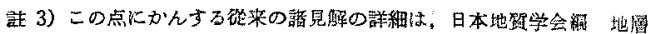

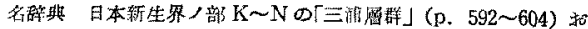

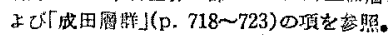

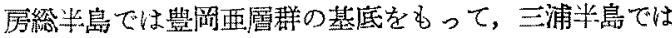

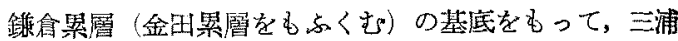

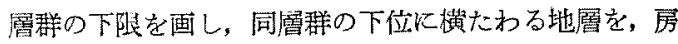

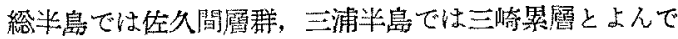
Wた。

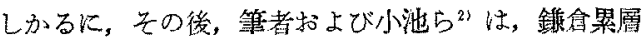
と三崎累居との間には，層群の単位でわけなければなら ない汪との岩相上の特徽の大きな変化性そみ上かがたい

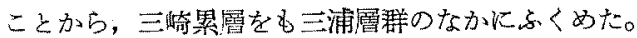

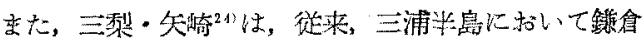

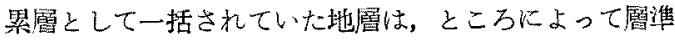
がいらじるしくことなることをあきらがし，同半島中 部の北部の高部一堀〉内地域の目越川砂㜰岩層々，その

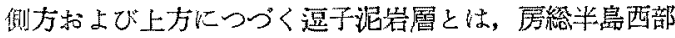

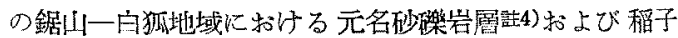
沢泥些圈に，杰，同半岛中部の小系川一金山川地域に

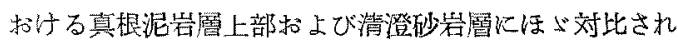
るが，三浦半島中部の南部の久留和一千騳ガ渏地域の田

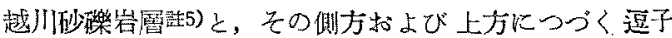
泥岩筧とは，房総半島中部の小采川一釗山地域に和け る基根泥岩層にほよ゙対比されるるのとした。三梨・知㥓 は，三崎累層の漛準についてはまったく言更していな

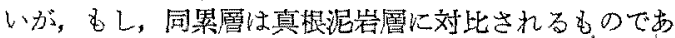

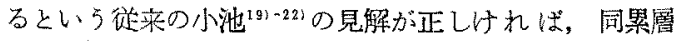

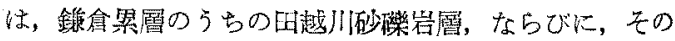
側方和よび上方につつく運子泥岩層の备一部とも，近い 屬準のものとなる。

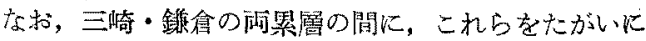

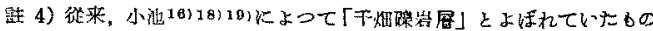

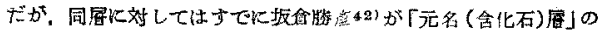

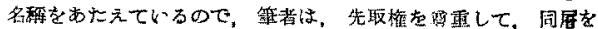
「元名形少岩展」と上がことにする。

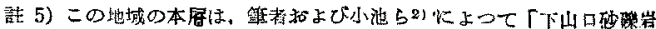

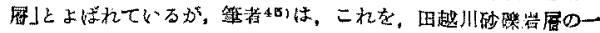

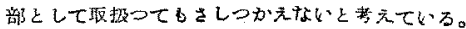


軟体動物化石からみた居総・三浦雨半岛の三浦層群の年代扣よび対比の問題（その1）

第 1 表三浦層群 の区分表

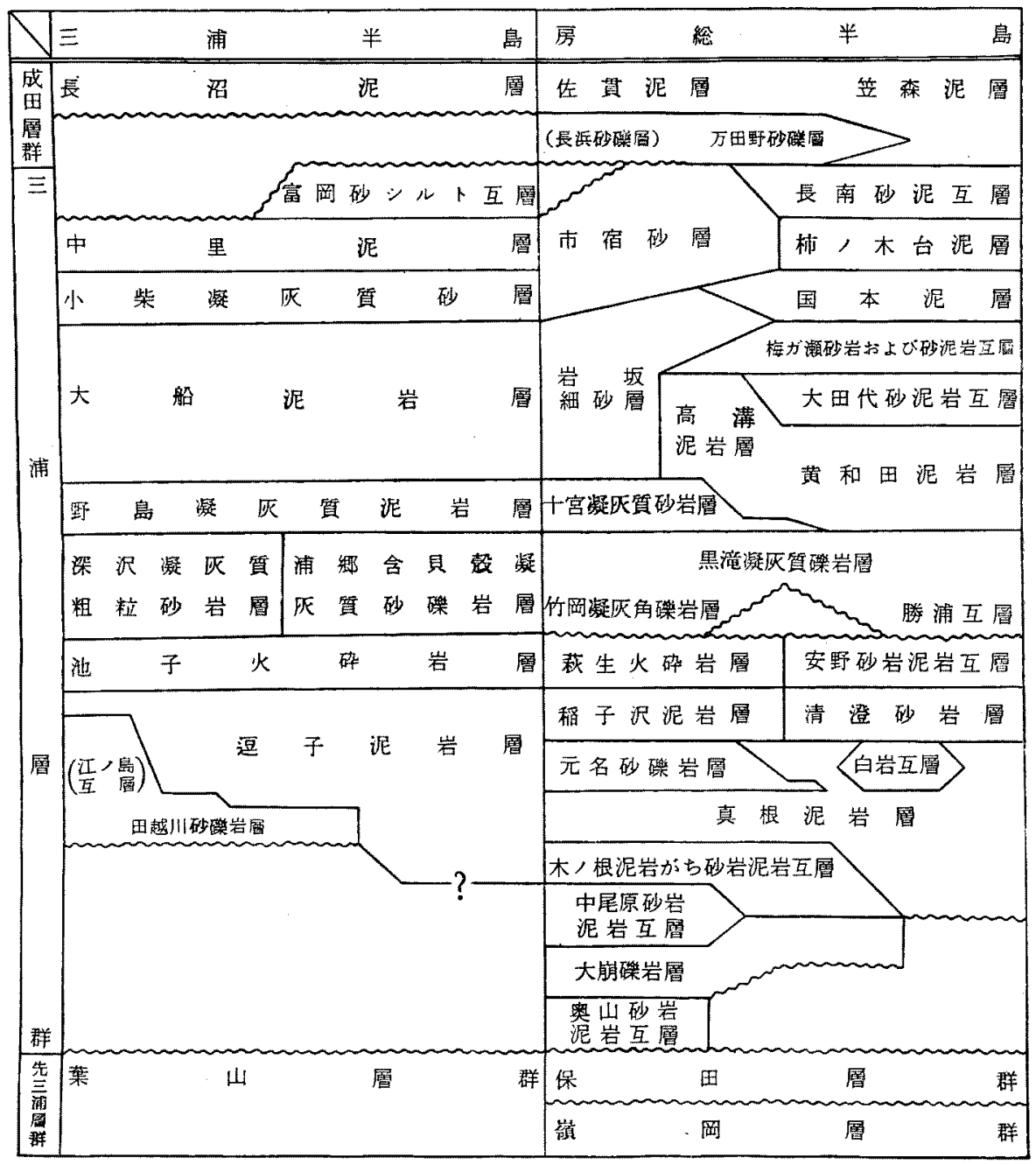

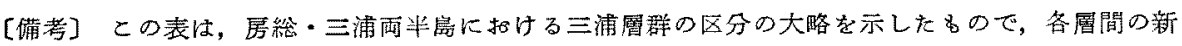
旧上下保は，かならずしす正確に表現されていない。たとえば，大田代砂泥岸互層は，

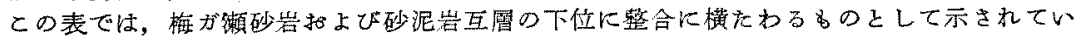

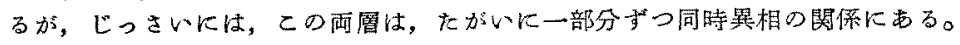

別個の果層として区別しうるだけの岩相上の特徵の差別 性があるか否かは，再㛟討を要する問題であるが，三崎 累層からは，軟体動物化石の産出がをだしられていない ので, 小論では，兩累買の区分の問題には，これ以上ふ れないでおくことにする。

いっぽう, 三梨・矢猗は, 房総半家において, 小

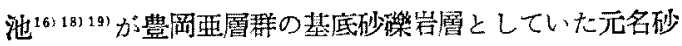
㹡岩層は，同半島中部の小系川一金山川断面では，豊䦌 西層释下部の清澄砂岩啳の基底には位置せず，同砂岩層 と佐久間層群上部の真根泥岩層との境界から約 $250 \mathrm{~m}$ 下
位の真根泥岩層中心介在する凝灰質秒岩屏につふくくの でることをたしかめて，元名砂鿬岩層の基底をもって 三浦層群 (豊阙亚層群) と佐久間層群との境界を画する ことの妥当でないことを指摘している。よって，小論で は，この三梨・矢崎の見解をいれて，往来，小池が佐久 間層群にぞくさせていた地居をすずてて三浦尿群にふく めることにする。

(2) 三浦層群の上限の問題 三浦罜群の上限の問題 についても，従来から，多くの見解が表明されている。 三浦半島では, 長沼層の基答の不整合をもって, 三浦層 


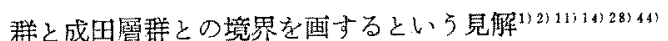

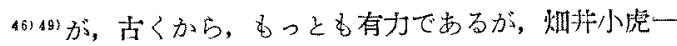

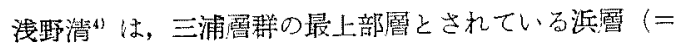

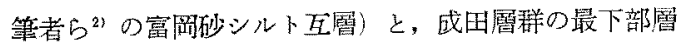

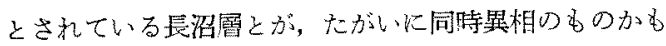
しれないとい5見解をのベた。この見解は，長沼尿が浜 層の下位の中里泥膡を被うところはあるが, 長沼層が浜 層を被らとこるはしられていないとい5, 野外の重実加 らみるびかれたものと推定される。しかし，唇沼層と捠 層とが，たがいに側方に移化するという事実む，栗だた しかめられていないので，两層が，はたして上下関係に あるものか，それとも，同時異相の関保にあるものか はここえにちでは，またあきらかでない。よって，小論 では，從来の多くの人たらの見解どおり，浜買は三浦尿 群に，長召層は成田層群にふくめることにする。

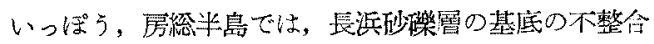
をもって西層群の境界を画するといら矢部長克 ${ }^{91}$ ・植田

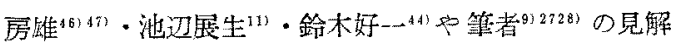

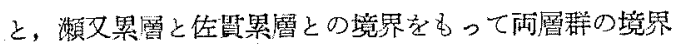
を画するという最近の池辺 ${ }^{13)}$ や小池洗 - 成瀬洋 ${ }^{231251}$ の見 解とが対立している。しかし，長浜砂碑霄の基底の不整 合は，半帛の西部のみにむって，中東部では消失し，杰 た，瀬又累圈の基底には，半島の東部では不整合がある が，中西部では，不整合の存在がまであきらかにされて いないので，上記の両見解のちちのいずれをとっても， 三浦・成田の両䚄を, 半島全域にわたる不整合で区分 することにはならない。の片，房総半島の西部では，

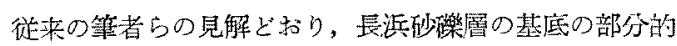
不整合をもって，两屬の境界を画することにし，この 不整合が消失している半島の中柬部では，長浜砂碎層の

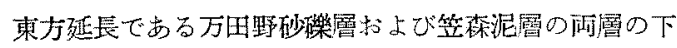

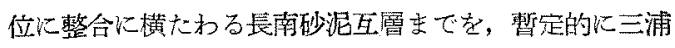

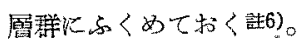

\section{(3) 三浦層群の区分の問題小詇では, 三浦層群の} 上下两限を，以上のようにさだめることにより，同㿉群 を，第1表に示したように区分する䛨7。

\section{III. 三浦層群産のおもな軟体動物 化石の垂直的分布にういて}

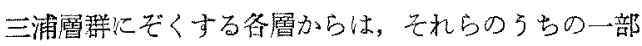

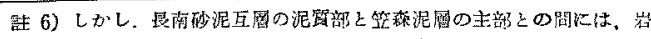

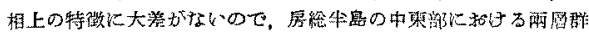

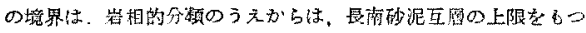

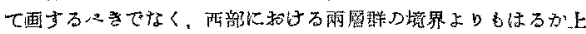

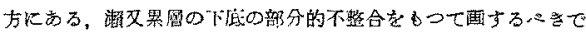

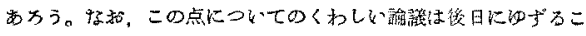
とにする。

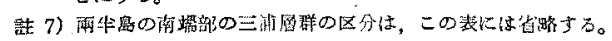

のものをのぞいて，種数おょび俔体数にかなりの差はあ るが，軟体黟物化石を産する。そしてこれらのなかた は，ある特定の塬淮を示すとされている種類も，いくつ

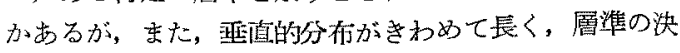
定に忧ったく役立たないと考点られている種類む, 忛 っして少なくない。

つきにここれらの諸種の5ち，等者をふくも最近の多 くの人たるの調查利究の結果, 垂直的分布にかんする知 識が大幅に変更されたものについて，新らしい知識によ

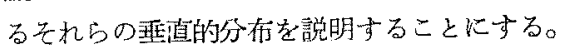

(1) Ancistrolepis trochoideus (DALL) 屏総半島で

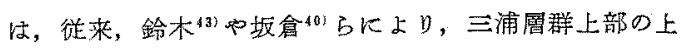
半部 (二鈴木・坂倉らの里見続) 加 万，典型的な媣海棲種 である Ancistrolepis trochoideus (DALL) の産出が報告 されていた。

しかるに, 最近, 畑井ら ${ }^{5187}$ は, 本種は, 三㵝層群上 部の下半部 (二鈴木・坟倉らの西烟䋶) の上部の大田代

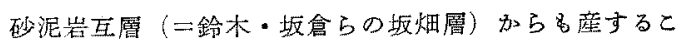
とを報じ，さらに，最近の筆者の調查によれば，本種 は，大田代砂泥岩互層の下位の黄和由泥岩層（二鈴木 * 坂倉らの小平が台泥岩層）からも，かなり普遍的几産す る。また，筆者は，三浦㬝群下部の中部の 1 層である白

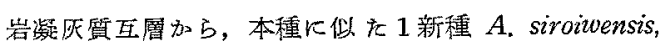
sp. nov,を発見している。

したがって, 房棇半島では, 良来, 三浦層群上部の上 半部に加さるとされていれ Ancistrolepis 属の垂直的分

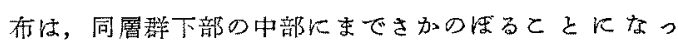
た。

以上の和か, 鈴木 ${ }^{43}$ によれば, 坂畣は, 不完全な破片

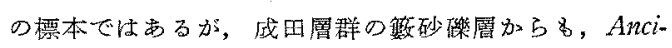

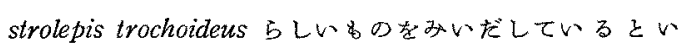
われ，坂倉 ${ }^{41}$ の數砂确層産の化石表（虐地番号 57）下 わ, 本種がのっている。しかし, 筆者は, 同屬から, 坏

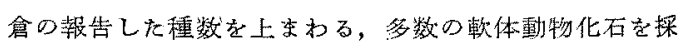
集しえたにもかつわらず，まだ，本種を発見するにいた っていい。

な找，三浦半島加らは，Ancistrolepis 属の化石の應出 は、乙れまで報告されたととがなく, 筆者も, その㡾出 をまだ確諰していない。

(2) Denialium yokoyamai MAKIYAMA 本種は中 新世から現世にわたる，きわめて長い垂直的分布をるっ たものであるが，三浦層群のなかでも，かなり長い垂直 的分布を西てている。

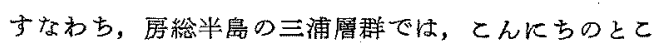

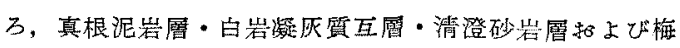

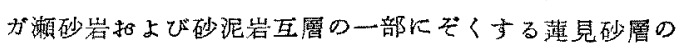


みから，本種の産出加しられているのに対して故8)，三 浦半島の三浦缯群では, 真根・白岩・清澄の各圈に奶比

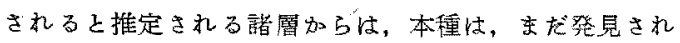

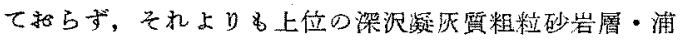

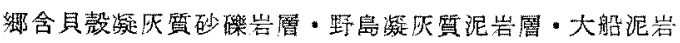

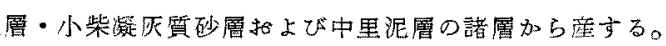

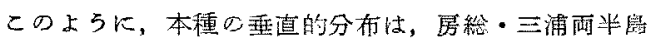

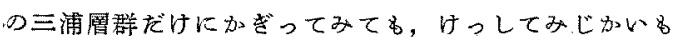
のではないだけでなく，その鷹出層準は，地域でをに， かなりととなっているのである。

(3) Palliolum peckhami (GABB) 本種は, 彷来南

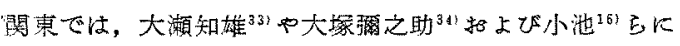
よって, 房総半岛の真根泥岕層註9)のみから, その座出

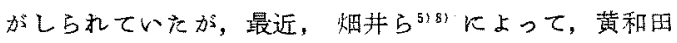
泥岩層汃らる報告され，さらに，笽者は，上記の雨層の

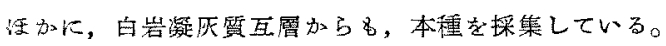
したがって，岸総半島に抬ける本種の垂直的分布は，加 なり長いるのとなる

(4) Chlamys miurensis(YOKOYAMA) 本種は, 良

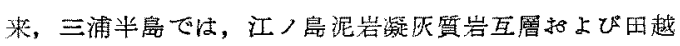

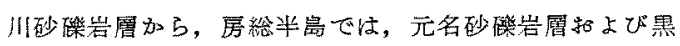

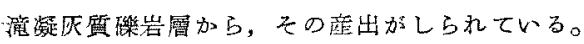

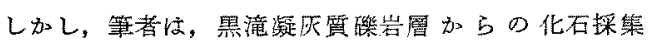
住，かなり大規模に和てなったるか小からず，同層か

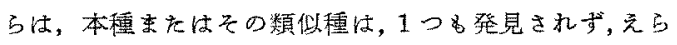

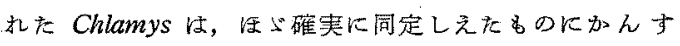
るかをり，后戴の Chlamys 属に心くをれる Aequipecten vesiculosus (DUNKER) だけであった。

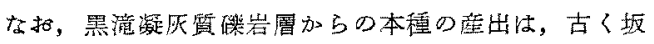

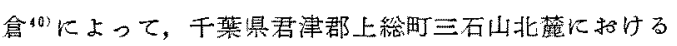

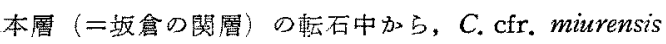
として郝告されたるのが最初の上らであるが，その後，

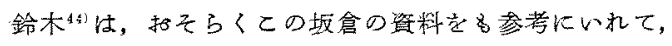
鋸山統下部の閔階の基底加ら本種索産するとし, さら

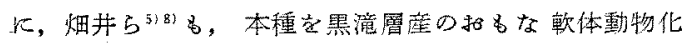
石の1つとしてあげている。

元名砂碩岩層加らの本種の座出は, 上治寅次郎 ${ }^{481}$ 中大

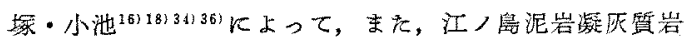
互層からの産出は，筆者把よび小池ら”によって報告さ

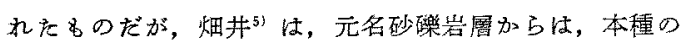
㡾出を報ぜず，そのかわりに，Miyagipecten matsumo-

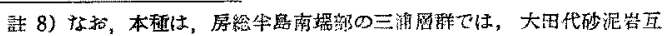

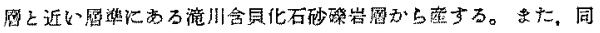

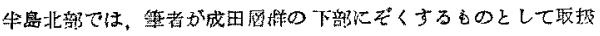

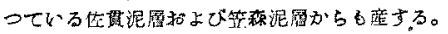

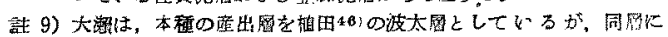

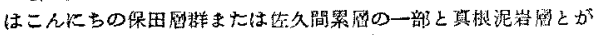

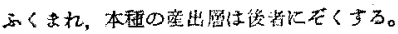

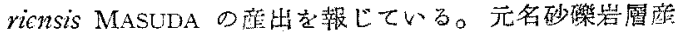

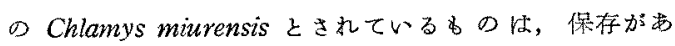

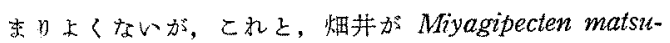
moriensis そしたもの上は，古るいは，同一種である可 能性もある。

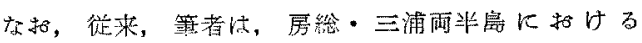

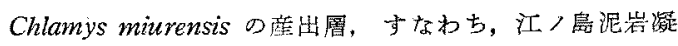

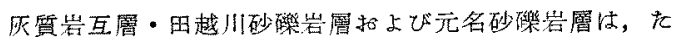

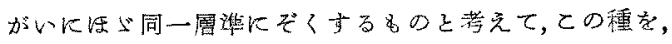

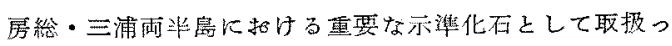

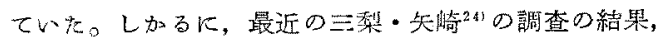
田越川砂碷岩尿は，コころによってその層集がいちじる しくこをなり, 同層に把ける本種の諸化石産地のらちの

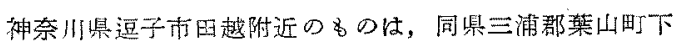
山口附近のめの上りも，はるかに上位に位するととがあ 李らかにされたので, 本種の重直的分有は, 徉来考えら

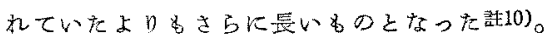

(5) Pecten albicans naganumanus YOKOYAMA 本

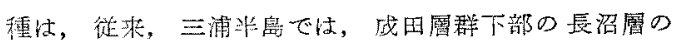

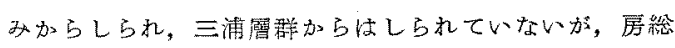

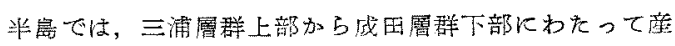

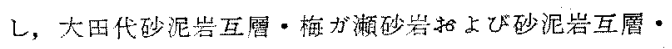

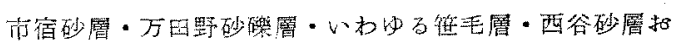

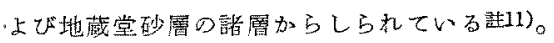

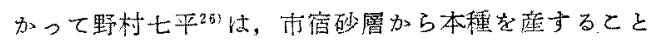

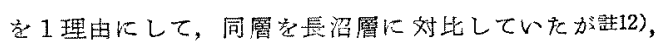

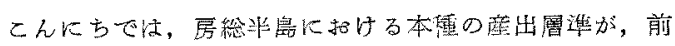
記のよらに, 上下にいちじるしくのびれので, 本種は,

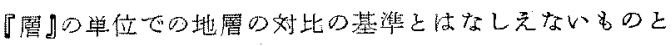
tho

6) Lima zushiensis YOKOYAMA 本種估, 従来,

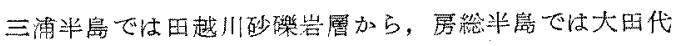
砂泥卧亚層の汁森化石带加らしられていれが, 最近, 畑

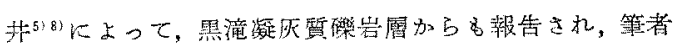

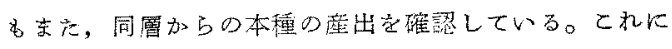

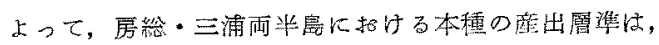

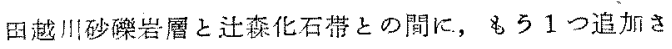

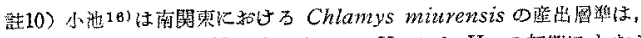

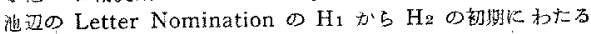

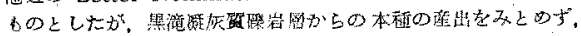

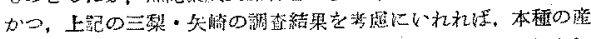

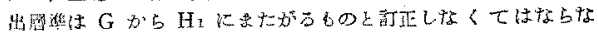
$r^{2}$

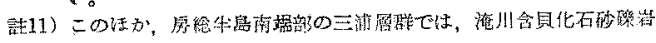
痈から壁吉る。

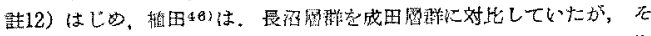

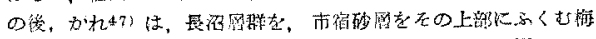

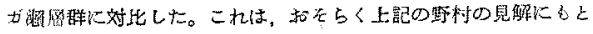
らいたものでらうっ。 
れるととになった。

(7) Lima quantoensis YOKOYAMA 本種は, 従来, 三浦半島拇よびその北隣地域では，小柴凝灰缶砂層扔よ

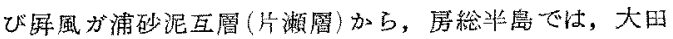

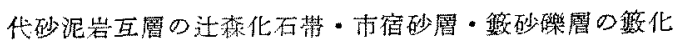

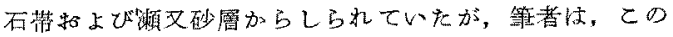

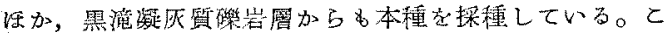

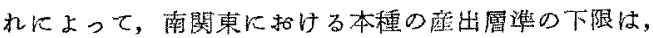
彷来しられていたよりも，きらに下方にまでさげられる KWkった。

(8) Akebiconcha nipponica (OINOMIKADO \& KANEHARA）現在しられている本種の痤出風準は，房等・ 三浦雨非鼠のいげれに和いても，それぞれ，たぶ1つに

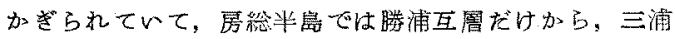
半富では池子火破崖層だけから㢈する。しかし，これら

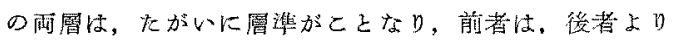

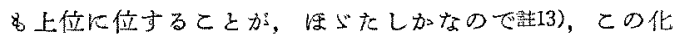

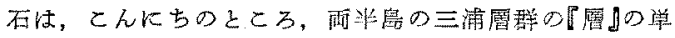
位での対比には朋いるととがでをない。

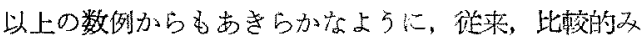

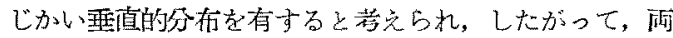

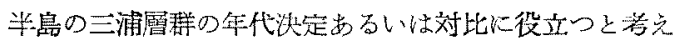
られていた種賏のなかにも，調查研究の谁展にともな い，その瑟的分布がさらに上方または下方にのびる いたったものが，少なからず存在している。

このため，ある特定種の国直的分布にかんする知部だ

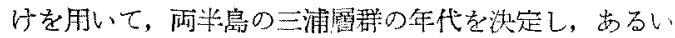

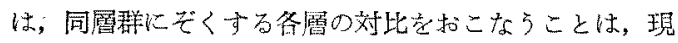
状では，きわめて因難になっているのである。

\section{VI. 三浦層群虐の軟体動物化石群集について}

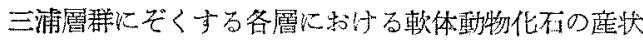

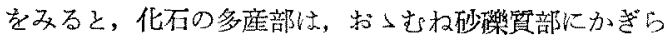

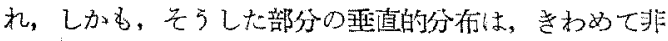

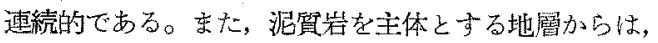

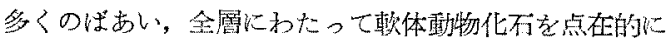
㡾するが，その重䣫的変化は，きかめてとぼしい。

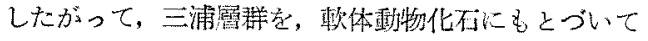
化石篔序学的汾分すことは，現状では，すこぶる团 難であり，この区分叔こなうためには，なお，かなり 大規模な化石探集を必要とする状態にある。

しかし、ごく大まかにみるならば，三浦尿群のなかに は，つぎの上らな諸化不群集の存在することを指推でき ろ。

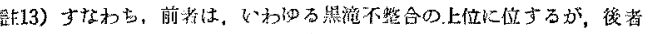

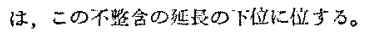

(1) Placopecten akihoënsis Aequipecten vesiculosus var. 1 - Crassatellites cfr. namus 群集

Conus sp., Placopecten akihoënsis (MATSUMOTO), Aequipecten vesiculosus (DUNKER) var. 1, Crassatellites cfr. nanus (A. ADAMS \& REEVE) などの諸種から

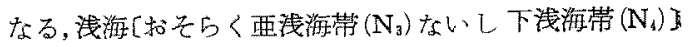

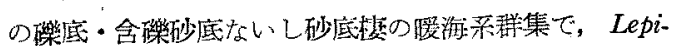
docyclina nipponica (HANZAWA), L. japonica YABE, L. makiyamai MORISHIMA, Miogypsina kotoi HANZAWA, Amphistegina radiata: (FICHTEL \& MOLL) などの

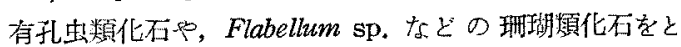
まなっている。この集は，千荣県安房郡勝山町乱よび 保田町方面の奥山砂岩泥岩互層・大崩碗岩層および中尾 原㫾岩泥岩互層の諸尿のなかにふくなれているが，この 群集の構成要素は，座地ごとに，多少ことなって物り， 生大，化石の保存状態がわるくて，その内容の充分あき らかでないところむ多い。

(2) Glycymeris derelicta - Venericardia ferruginosa 群集 Glycymeris dereticta(YOKOYAMA), Venericardia ferruginosa (A. ADAMS \& REEvE) など

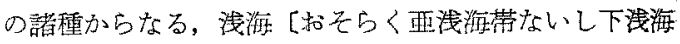
帯」の砂底娶の䁔海系集で, Lepidocyclina sp.などの

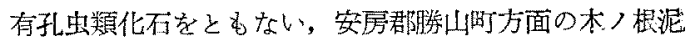

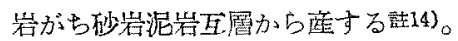

(3) Dentalium yokoyamai - Palliolum peckhami-Thyasira disjuncta 群第 Dentalium yokoyamai MAKIYAMA, Palliolum peckhami (GABB), Thyasira disjuncta (GABB) などの簿種からなる, 下浅海带

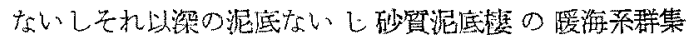
で, Makiyama chitanii (MAKIYAMA) をともない, 真

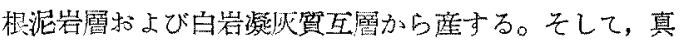

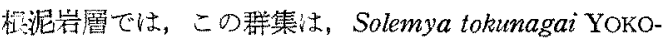
YAMA, Lucinoma acutilineatum (CONRAD), L. olukai HATAI \& NISHIYAMA, L. spectabilis YOKOYAMA など

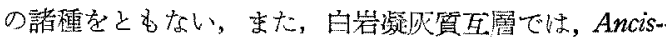
trolepis siroiwensis, sp. nov. などをとるなっている。 な执，真根・白岩の再鼠は，岩相上の特徽がたがい儿

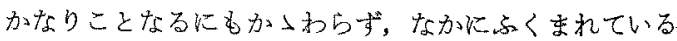

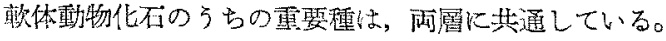
このことから，雨圈の沈程環境は，さほどことなってい

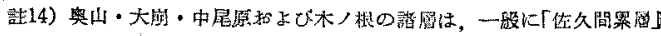

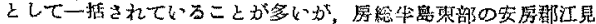

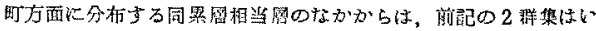

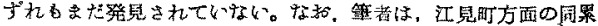

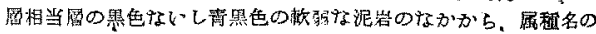

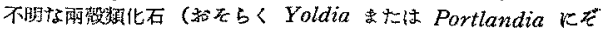

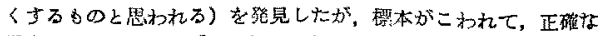
鑑空を和こなうこにがでをながだ。 
なかったと挂定される䚴15)。

(4) Chlamys miurensis-Amussiopecten praesignis 群集 Umbonium yabei SUGIYAMA, Glycymeris rotunda (DUNKER), G. sp. nov, $\alpha, G$. sp. nov. $\beta$, Chlamys miurensis (YokOYAMA), Amussiopecten praesignis (YOKOYAMA), A. planicostulatum (NOMURA \& NINO), Lima zushiensis YOKOYAMA, Ostrea musashiana YOKOYAMA などの諸種からなる，西浅海

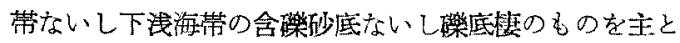

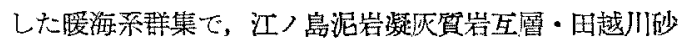

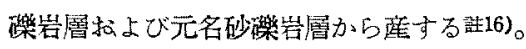

この群集は，多くのばあい，化不塊・化石堆するいは

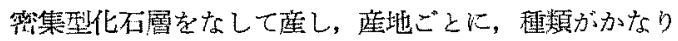
ことなるととるに，同一種の座出將度もかなりことなっ ている。たとえば, Chlamys miurensis は，神奈川県藤

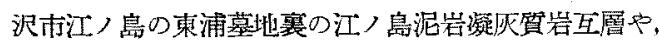
逞子市田越附近和上び三浦方初声町下㖟田附近の田越川 砂䃏岩層からは，きかめて多く産するが，横須賀市瓜笠 附近や三浦郡菜山町下山口附近の田越川砂樂岩層名 5 は，比較的稀にしか産しない。また，Amussiopectenは

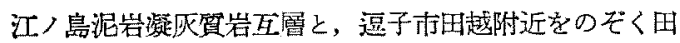
越川砂础岩曯とからは，また発見されていないが，将 来，さらに大規模な化石採集を和こなえ弪，これらの备 層からむ登見される可能性がある。

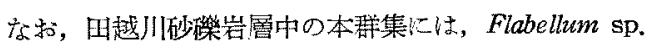
などの㑚哺䅡化石をともなうものた，Balanus sp. の破

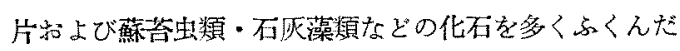
灰結介履岩のなか在しているものがあり，また，元 名砂然岩㞒中の本集には, Echinolampas yoshiwarai P. DE LORIOL などの海胆類, Isurus hastalis AGASSIz

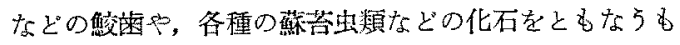
のがある。

(5) Glycymeris nakamurai-G. totomiensis 群 集 Cancellaria miranda (YOKOYAMA), Glycymeris nakamurai MAKIYAMA, $G$. totomiensis MAKIYAMA, Ostrea gigas THUNBERG などの諸種からなる, 浅海(お゙ そら〈亜浅海带)ないし下浅海带の含陊砂底小い儿砂底 楚の暖海系集で，清澄砂岩層の一部加ら䳸する。な

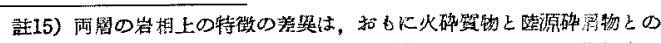

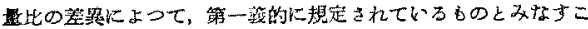
之小场了。

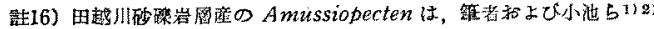

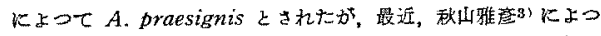
$\tau$ A. planicostulatum とされている。ゆ元, 同圈应の

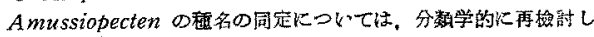

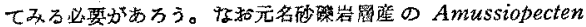

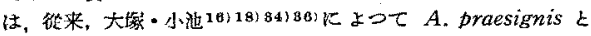

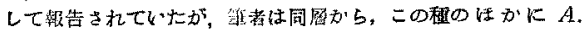

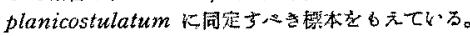

扔，本群集の一部は，Balanus sp.の破片や，炭化した 樹幹片などを多くなじえたいるら゙るしい介砂岩のなかに。

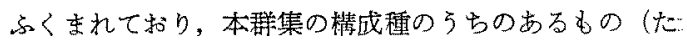
と觉ば, Ostrea gigas など) は, 潮間带 $\left(\mathrm{N}_{0}\right)$ または上. 浅海带 $\left(\mathrm{N}_{1}\right)$ 走中心とする海底の浅所から，亜浅海带な いし下浅海带の海底の深所へ運搬されたるのであるうと 堆定昰机る。

(6) Thyasira disjuncta - Lucinoma acutilineatum 群集 Solemya tokunagai YOKOYAMA, Thyasira disjuncta (GABB), Lucinoma acutilineatum (CONRAD）などの諸種からなる, 半樑海带の泥筫瓦梅の瞹海-

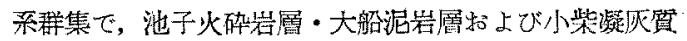
砂国の备一部からしられている。そのほか, 攻詹 ${ }^{403}$ によ

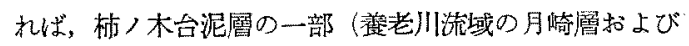
根古屋泥啳）から座する詶17)。

な叔，前述の上5に，真根泥岩尿の一部には，本磁集 の一買とみなすべきものがあり，また，後这のように，

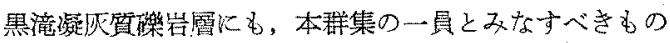
劦する。

(7) Akebiconcha nipponica 群集 Akebiconcha nipponica (OINOMIKADO \& KANEHARA) を主とする半. 樑海带の泥庭掉の群集で, Turcicula sp. などをともな うことがあり，勝浦互屬および池子火础岩畨から産す 万。

\section{(8) Arca miyatensis Volsella nipponica 群莱}

Turcica sp., Crepidula cfr. grandis MLDDENDORFF, Serpulorbis sp., Buccinum sp., Conus tokunagai OTU. KA, Arca miyatensis ÔYAMA, Pseudogrammatodon dalli obliquatus (YOKOYAMA), Aequipecten vesiculosus (DUNKER), Lima quantoensis YOKOYAMA, Volsella nipponica ÔYAMA, Solamen diaphana (DALL), Thyasira'

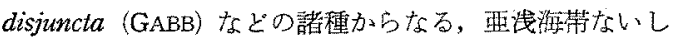

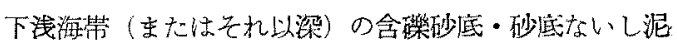
底婪の暖海系集で，Flabellum transversale MOSELEY などの 現瑚熲や, Terebratatia gouldi DALL, Laqueus rubellus (SOWERBY) などの腕足類, Hydroides reticulatus (YOKOYAMA) などの環出類なとの化石をともなっ

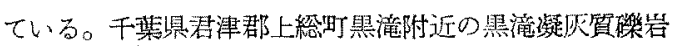
䙓のなかが，化不啨するいは化石堆をなして，密集的 に座するが, とくに, Arca miyatensis, Volsella nipponica, Thyasira disjuncta などの諸種がぬだ。

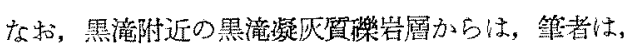
まだ, Lucinoma acutilineatum (CONRAD) を探等してい

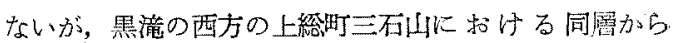

仹17) しかし，籍者は、この喝からは, Lucinoma acutilineatum を またみくたしていない。 


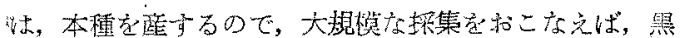
滰附近から日，本種が振集される可能性がある。したが ○一, 本群集江, Thyasira disjuncta-Lucinoma acutilineatum などが流入混合したすのと友な心きものかもしれな w。

(9) Glycymeris rotundo-Aequipecten vesiculosus-Lima zushiensis 群集 Glycymeris rotunda (DUNKER), Limopsis sp. 1, L. sp. 2, Aequipecten vesiculosus (DUNKER), Lina zushiensis YOKOYAMA, Crassatellites cfr. oblongatus (YOKOYAMA), Lucinoma acutilineatum (CONRAD), Nemocardium samarangae (MAKIYAMA), Oxyperas bernardi (PILSBRY) などの啫 種からなる，西浅游带ないし下浅海带（またはと机以

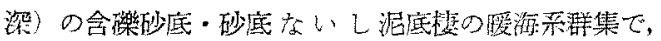

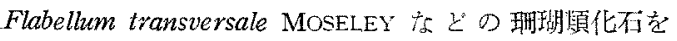

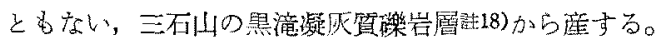

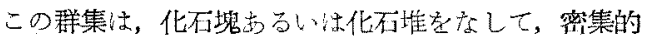
飞座与るが，一般に，㑑体数の多い放りあいには，曆数 は多くなく, Glycymeris rotunda 拈よび Aequipecten

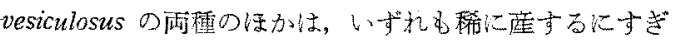
tels

(10) Dentalium yokoyamai-Glycymeris rotunda-Limopsis tokaiensis var. 群 Dentalium yokoyamai MAKIYAMA, Glycymeris rotunda (DUNKER), Limopsis tokaiensis YoKoYAMA var., L. crenata A. ADAMS, L, azumana YOKOYAMA, Patinopecten tokyo-

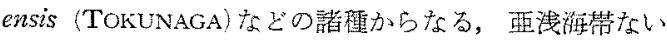
し下浅海带の泥質砂ないし砂底模の䐘海系集で, 神奈

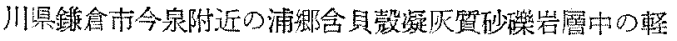
石算粗精砂のなかなどにみられる。

(11) Dentalium yokoyamai-Limopsis tajimae var. 群菒 Turcicula argenteonitens hirasei TAKI \& OTUKA, Turritella nipponica nojmaensis IDA, Beringius adelphicus (DALL), Dentalium yokoyamai MAKIYAMA, Acila "divaricata (HINDS)", Glycymeris nipponica (YOKOYAMA), Limopsis tajimae SOWERBY var., Patinopecien yessoensis (JAY) var., Lucinoma annulatum (REEVE) などの偝種からなる，业浅海带な

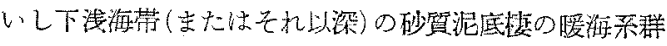

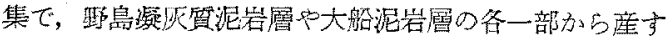
公。

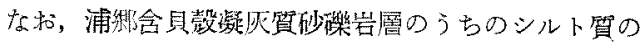

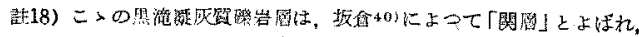

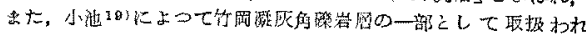
$\tau k \oiint_{0}$
部分にも，Limopsis tajimae var.などのらくな礼てい ることがあり，本群集高たは次記の Trophon xestra nipponicus -Fulgoraria kosibensis - Limopsis tajmae var、翟策の一貝とみなすことができる。

(12) Trophon xestra nipponicus-Fulgoraria kosibensis-Limopsis tajimae var. 群䈏 Fusitriton oregonensis? (REDFIEID), Trophon xestra nipponicus YoKoyaMa, $T$. echinus DALI, Mitra yokoyamai ÔTUKA, Fulgoraria kosibensis ÔTUKA, Cymatosyrinx braunsi (YOKOYAMA), Spirotropis kazusensis ÔTUKA, Brachytoma takeokensis ÔTUKA, Riuguhdrillia mediocarinata (YOKOYAMA), Limopsis tajimae SOWE-

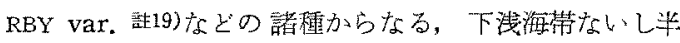

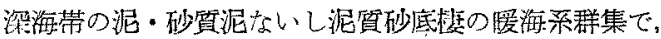

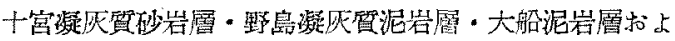
び小柴凝灭筫砂圈の各一部から虐する。しかし，この群 集は，库地ごとに，種類がかなりことなっている。

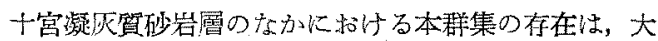

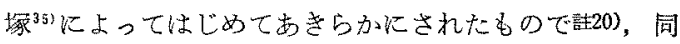

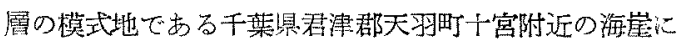

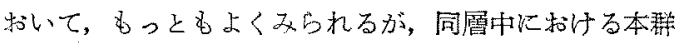
集の水㸵的分布は，現在しられているがきりでは，きか めて猐く，同層が東方に次第に薄くなるとともにこの 特徽的な群集も及られなくなる致21)。

なお，三浦半島では，本群集は，前記の Dentalium yokoyamai-Limopsis tajimae var. 群集と其存している ものとみなすことができる。

(13) Limopsis uwadokoi-Ancistrolepis troch. oideus 群集 Ancistrolepis trochoideus(DALI), Antiplanes contraria (YOKOYAMA), Riuguhdrillia mediocarinata (YOKOYAMA), Dentalium rhabdotum PILSBRY, Portlandia japonica (A. ADAMS \& REEVE), P. lisch kei (E. A. SMrTH', Limopsis uwadokoi OYAMA (MS),

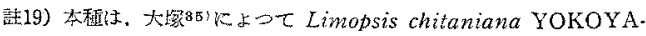

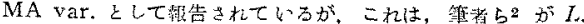

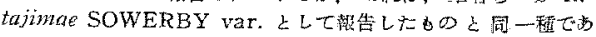

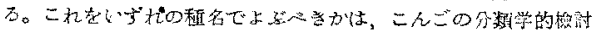
にキつことにすっ。

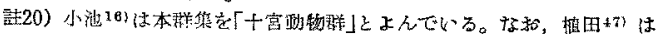

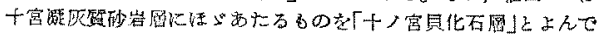
買化石群索壁するこを指摘しているが，その内容には采つたく ふれていない。

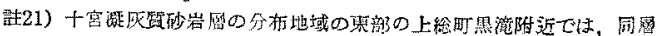

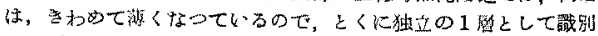

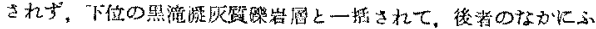

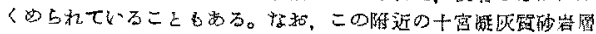

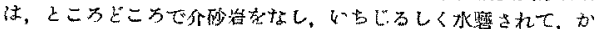

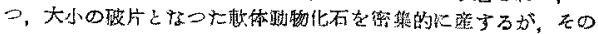

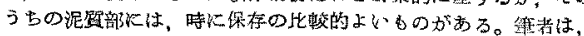
この部分加 5 , Chlamys sp., Thracia? kurotakiensis, sp. nov, 极当学探集している。 
Palliolum peckhami (GABB), Polynemamussium alask. ense (DALL), Solamen diaphana (DALL) などの諸嚇か

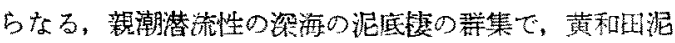

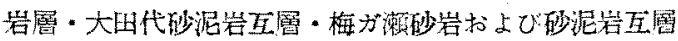

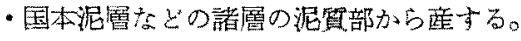

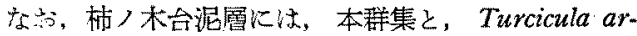
genteonitens hirasei TAKI \& OTUKA, Fusitriton oregonensis \REDFIELD〉, Limopsis tajimae SOWERBY to

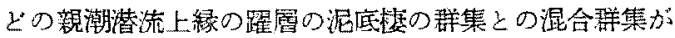

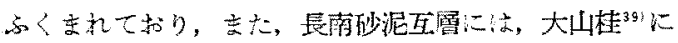

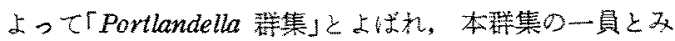
なさ㣗たすのがある。この Portiandella 群集は, Portlandia (Portlandella) lischkei (E. A. SMTTH) まる, 深海区の泥底㮃の集で, Buccinum sp. indet., Nuculana yokoyamai KURODA, $N$, ikebei SUZUKI \& KANeHARA, Porllandia lischkei (E. A. SMITH), Limopsis uwadokoi OYAMA (MS), Serripes sp. indet., Macoma calcarea (GMELIN) などの諸種からなり，榓荫

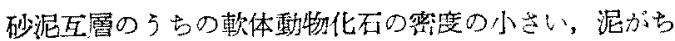
の部分のなか的らくれている。

(14) Glycymeris pilsbryi-Fecten albicans naganumanus-Aequipecten vesiculosus 群集 Acmaea pallida (GoULD), Leptothyra sangarensis (SCHRENCK), Amalthea conica SCHUMACHER, Proterato

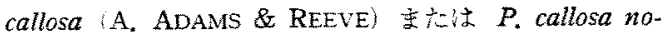
murai HATAI \& NISIYAMA, Olivella fabula (MARRATT) var., Conus tuberculosus TOMLIN, Glycymeris pilsbryi (YOKOYAMA), G. rotunda (DUNKER), Limom psis tokaiensis YOKOYAMA, Aequipecten vesiculosus (DUNKER), Pecten albicans (SCHRÖTER), P. albicans naganumanus YOKOYAMA, Ostrea musashiana YOKOYAMA, Venericardia ferruginea CLESSIN, Chama fragum REEVE, Nemocardium samarangae (MAKIYAMA), Venus toreuma GOULD などの諸種からなる, 亚浅海森

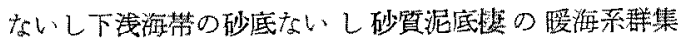

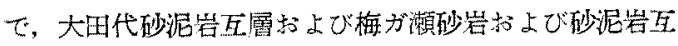

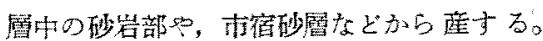

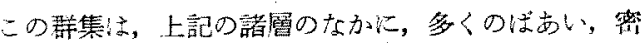

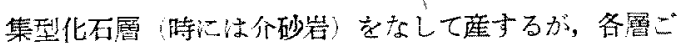

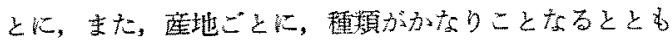
に，同一種の学出頻度もかなりことなっている。

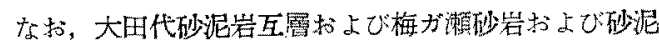
岩互尿では，本群集をらく秒岩尿は，前記の'Limopsis

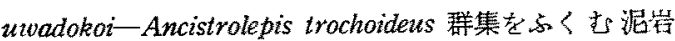

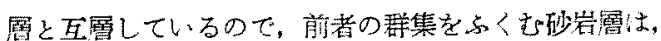
啳者の群集をふくさ泥岩尿とほぶおなじ深さの海底に沈
鄯したすのと推定される。

(15) Yold ianaganumana Yoldia naganu-

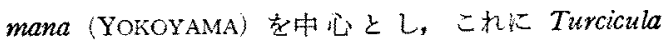
sp., Acila "divaricala (HINDS)", Nuculana (Thestyleda) sp., Limopsis tajimae SOWERBY var.などを

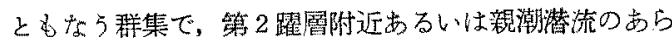

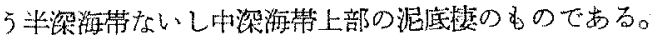

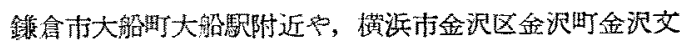
㢆附近の大船泥岩罢および櫝浜市戸塚区長沼们地方の中 里泥舆加库与る。

(16) Limopsis crenata-L. tokaiensis-L. azumana-Venericardia ferruginea 群集 Limopsis crenata A. ADAMS, L. tokaiensis YOKOYAMA, L. azumana YOKOYAMA, Venericardia ferruginea CLESSIN

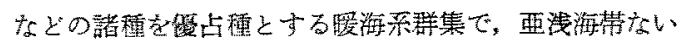

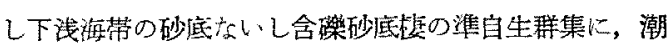
間带 $\left(\mathrm{N}_{8}\right)$ ないし中浅海带 $\left(\mathrm{N}_{2}\right)$ の岩礁椟の他生群集が流

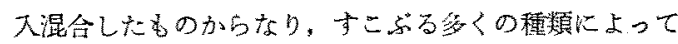

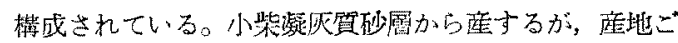
とに，種類がかなりことなるとともに，同一種の産出瀕 度むかなりことなっている棓22)。

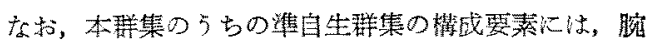
足頻化不力゙くくれている。

(17) Turritella ikebei-Limopsis tokaiensis var. 群集 Turritella ikebet KOTAKA, Dentalium yokoyamai MAKIYAMA, Limopsis lokaiensis YOKOYAMA var., Solamen sp., Lucinoma aculitineatum (CONRAD), Periploma sp. nov. などの諸稙からなる, 画浅游帶ないし

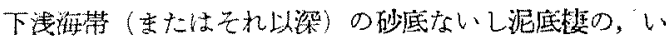

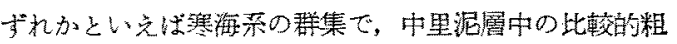
粒の部分から産寸る。

(18) Umbonium suchiense subsuchiense 群萎 Umbonium suchiense subsuchiense MAKrYAMA t中

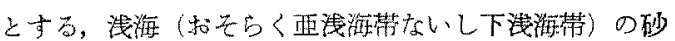

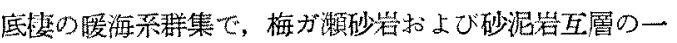

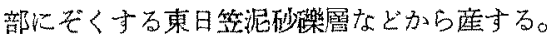

(19) Turritella nipponica kazusana-Venericardia ferruginea-Macoma tokyoensis 群集 Leptothyra amussitata (GOULD), Turritella nipponica kazusana IDA, Natica severa GoULd, Cancellaria spengleriana DESHAYES, Acila insignis (GOULD), Patinopecten tokyoensis (TOKUNAGA), Pecten albicans (SCHRÖTER), $P$. albicans naganumanus YOKOYAMA, Venericardia ferruginea CLESSIN, $V$. ferruginosa (A.

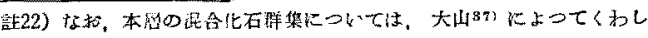
く揄討起机ている。 
ADAMS \& REEVE), Astarte hakodatensis YOKOYAMA, Macoma tokyoensis MAKIYAMA などの請種からなる,

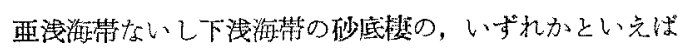
寒海系の群勧である。梅方瀨仯岩括よび砂泥岩互膡中の

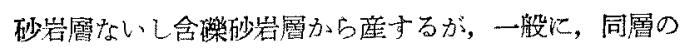
分有地域のうちの中四部に多く，東部には少ない。

(20) Macoma calcarea-Raeta rostralis var. 群 集 Macoma calcarea (GMELIN) 拉よび Raeta rost- ralis (DESHAYEs) var. を中心とし, これК Nuculana

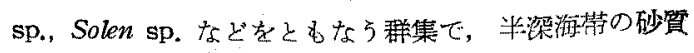

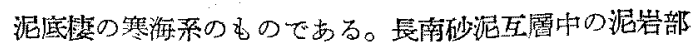

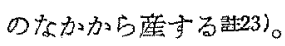

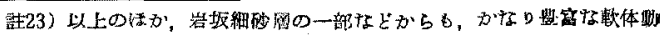

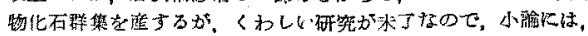
その碳明是省略する。 